Provided for non-commercial research and education use. Not for reproduction, distribution or commercial use.

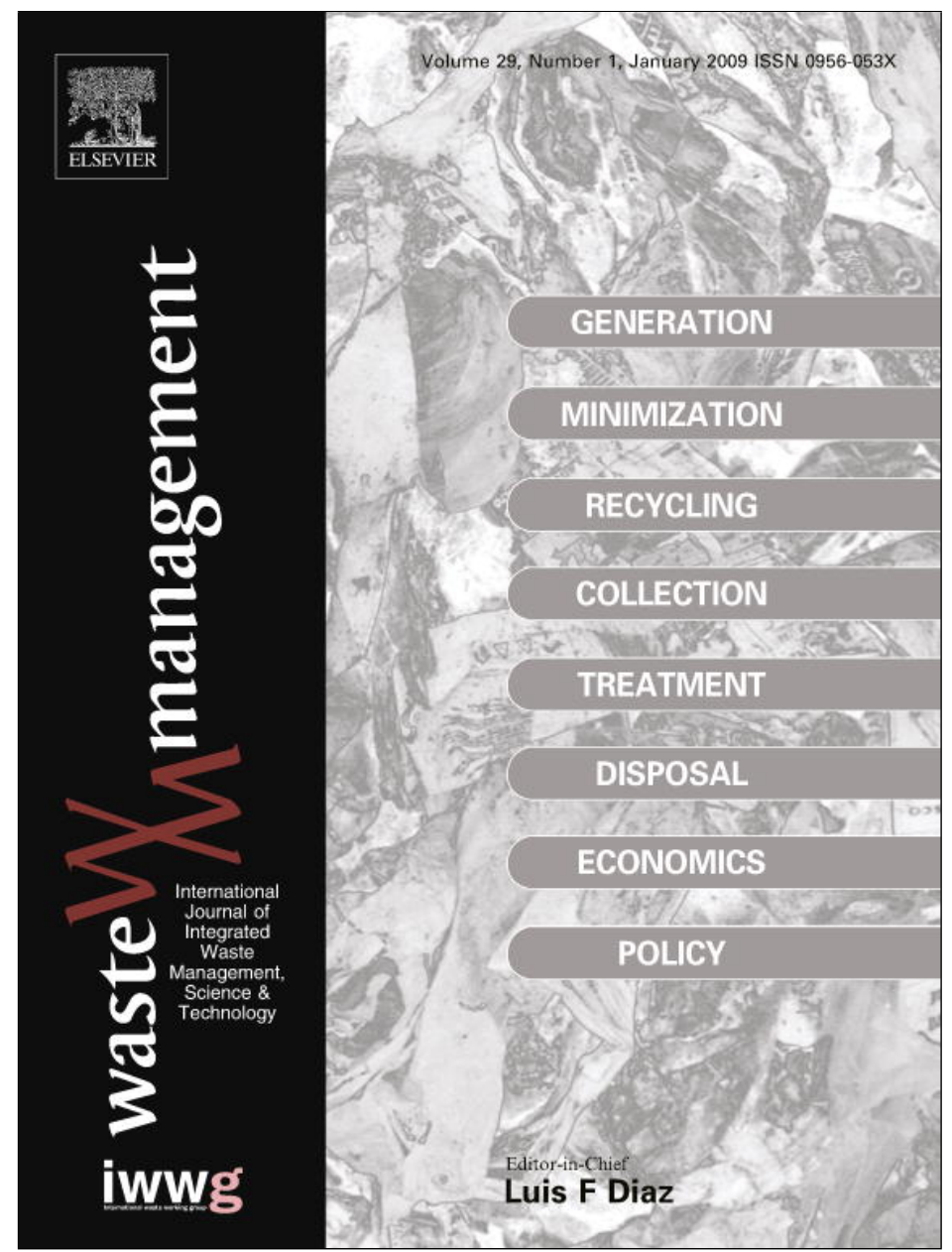

This article appeared in a journal published by Elsevier. The attached copy is furnished to the author for internal non-commercial research and education use, including for instruction at the authors institution and sharing with colleagues.

Other uses, including reproduction and distribution, or selling or licensing copies, or posting to personal, institutional or third party websites are prohibited.

In most cases authors are permitted to post their version of the article (e.g. in Word or Tex form) to their personal website or institutional repository. Authors requiring further information regarding Elsevier's archiving and manuscript policies are encouraged to visit:

http://www.elsevier.com/copyright 


\title{
Effect of compost application rate on carbon degradation and retention in soils
}

\author{
Adani Fabrizio*, Fulvia Tambone, Pierluigi Genevini \\ Dipartimento di Produzione Vegetale, Università degli Studi di Milano, Via Celoria 2, 20133 Milano, Italy
}

\section{A R T I C L E I N F O}

\section{Article history:}

Accepted 22 February 2008

Available online 8 April 2008

\begin{abstract}
A B S T R A C T
We investigated the effect of a single compost application at two rates ( 50 and $85 \mathrm{Mg} \mathrm{ha}^{-1}$ ) on carbon (C) degradation and retention in an agricultural soil cropped with maize after $150 \mathrm{~d}$.

We used both $\mathrm{C}$ mass balance and soil respiration data to trace the fate of compost C. Our results indicated that compost $C$ accumulated in the soil after $150 \mathrm{~d}$ was $4.24 \mathrm{Mg} \mathrm{ha}^{-1}$ and $6.82 \mathrm{Mg} \mathrm{C}^{-1}$ for 50 and $85 \mathrm{Mg} \mathrm{ha}{ }^{-1}$ compost rate, respectively. Compost $\mathrm{C}$ was sequestered at the rate of 623 and $617 \mathrm{~g} \mathrm{C}$ $\mathrm{kg}^{-1}$ compost TOC for 50 and $85 \mathrm{Mg} \mathrm{ha}^{-1}$ compost dose, respectively. These results point to a linear response between dose of application and both $C$ degradation and retention. The amount of $C$ sequestered was similar to the total recalcitrant $C$ content of compost, which was $586 \mathrm{~g} \mathrm{C} \mathrm{kg}^{-1}$ compost TOC, indicating that, probably, during the short experiment, the labile $C$ pool of compost $\left(414 \mathrm{~g} \mathrm{C} \mathrm{kg}^{-1}\right.$ of compost TOC) was completely degraded.

Soil respiration measured at different times during the crop growth cycle was stable for soils amended with compost $\left(\mathrm{CO}_{2}\right.$ flux of $0.96 \pm 0.11 \mathrm{~g} \mathrm{CO}_{2} \mathrm{~m}^{-2} \mathrm{~h}^{-1}$ and $1.07 \pm 0.10 \mathrm{~g} \mathrm{CO}_{2} \mathrm{~m}^{-2} \mathrm{~h}^{-1}$, respectively, for 50 and $85 \mathrm{Mg} \mathrm{ha}^{-1}$ ), whereas it increased in the control. The $\mathrm{CO}_{2}$ flux due to compost degradation only, though not statistically significant, was always greatest for the highest compost doses applied $\left(0.22 \pm 0.40 \mathrm{~g} \mathrm{CO}_{2} \mathrm{~m}^{-2} \mathrm{~h}^{-1}\right.$ and $0.33 \pm 0.25 \mathrm{~g} \mathrm{CO}_{2} \mathrm{~m}^{-2} \mathrm{~h}^{-1}$ for the 50 and $85 \mathrm{Mg} \mathrm{ha}^{-1}$ compost dose, respectively). This seems to confirm the highest $C$ degradation for the $85 \mathrm{Mg} \mathrm{ha}^{-1}$ compost dose as a consequence of the presence of more labile C. Unlike other studies, the results show a slight increase in the fraction of carbon retained with the increase in compost application rate. This could be due to the highly stable state of the compost prior to application, although it could also be due to sampling uncertainty. Further investigations are needed to better explain how the compost application rate affects carbon sequestration, and how characterization into labile and recalcitrant $C$ can predict the amount of $C$ sequestered in the soil.
\end{abstract}

(c) 2008 Elsevier Ltd. All rights reserved.

\section{Introduction}

With increasing $\mathrm{CO}_{2}$ emissions into the atmosphere and the possible consequences of global climate change, there has been growing interest in studying the contribution of sequestered carbon (C) in terrestrial ecosystems, i.e., the soil (Wang et al., 2004). In fact, although $\mathrm{CO}_{2}$ is primarily produced by fossil fuel combustion, land use changes have contributed significantly to atmospheric $\mathrm{CO}_{2}$ increases through the conversion of forest and grassland into agricultural land (Mosier, 1998).

The soil organic $\mathrm{C}(\mathrm{SOC})$ pool is the largest terrestrial reservoir of C (Lal, 2001). In fact, global soil-C is estimated to be $1200-$ $1600 \mathrm{Pg}$ and the estimated historic losses of $\mathrm{C}$ from agricultural soils amount to $40-60 \mathrm{Pg} \mathrm{C}$ (Paustian et al., 1997). The same authors argue that the above losses could represent a reference level for $C$ sequestration potential, i.e., the restoration to the native $C$ level represents the potential for $\mathrm{C}$ sequestration. In its Second

\footnotetext{
* Corresponding author. Tel.: +39 50316545; fax: +39 50316521

E-mail address: fabrizio.adani@unimi.it (A. Fabrizio).
}

Assessment Report, The Intergovernmental Panel on Climate Change estimated that it may be possible to sequester $40-80 \mathrm{Pg}$ of $C$ in cropland soils in the next 50-100 years, thereby confirming the above mentioned data (Cole et al., 1996). Thus, as agricultural soils are relatively $\mathrm{C}$-depleted, they represent a potential $\mathrm{CO}_{2} \operatorname{sink}$ if lost C can be regained (Paustian et al., 1997; Vleeshouwers and Veraghen, 2002).

Little data exist on the effects of compost use on C sequestration. Smith et al. (2005), discussing the potential of $C$ sequestration in Europe, underscored the lack of data on compost management as a means of $C$ sequestration. The fact that studies dealing with compost use generally focus on agronomic and chemical effects of compost on the soil rather than on $C$ sequestration explains the lack of available data (Gonzàles-Vila et al., 1999; Quèdraogo et al., 2001; Leifeld et al., 2002).

The term 'compost' refers to any material of various origins and with a wide range of composition that has undergone composting (Richard and Woodbury, 1992). Compost is a humic-like material that acts as an organic amendment because of its high organic matter $(\mathrm{OM})$ content. The composting process proceeds through the 
loss of more degradable organic materials and the concentration of less degradable materials, resulting in biomass enrichment of the humified materials (Lhadi et al., 2006).

Organic matter degradability is a key concept in soil OM studies and can be defined as the capacity of OM to be utilized by soil microbes as a source of energy (Rovira and Vallejo, 2002). Many parameters and indexes have been proposed in the past to measure $\mathrm{OM}$ degradability, e.g., $\mathrm{C} / \mathrm{N}$, lignin/N, and cellulose/lignin/N (Rovira and Vallejo, 2002). OM composition with respect to macromolecular components appears to be more important than the other parameters in determining degradability. For example, lignin, phenol, and tannin contents in the OM were more important in determining soil OM decomposition than $\mathrm{C}-\mathrm{N}$ ratio (Paustian et al., 1997). The more widely used models describing the soil-C cycle (e.g., CENTURY model; Izaurralde et al., 2001) divide soil-C and litter in different pools in relation to their degradability. As a strong correlation exists between the chemical and biological stability of $\mathrm{OM}$, the ratio of chemical-labile versus chemical-recalcitrant compounds is generally used to describe OM quality (Six et al., 2002; Mikutta et al., 2006). Rovira and Vallejo (2002) described plant residue degradability in the soil by dividing the OM into a labile and a recalcitrant pool, depending on the solubility of the OM in strong acids. These authors determined that the recalcitrant fraction content ranged from 250 to $650 \mathrm{~g} \mathrm{~kg}^{-1} \mathrm{OM}$ in this order: Medicago < Quercus < Eucalyptus < Pinus. Adani et al. (1995) divided the labile and recalcitrant OM fractions of compost by using a procedure similar to Klason lignin isolation. The partition of compost OM chemically into recalcitrant and labile pools has been shown to correspond to carbon retained and degraded after soil incubation (Rovira and Vallejo, 2002; Adani and Ricca, 2004).

The total amount of $C$ stored in the soil results from the net balance between input and output. Complete mass balance ( $\mathrm{C}$ balance), before and after soil amendment, enables the tracing of sequestered C (Lal, 2007). The soil-C pool comprises of two components: soil organic $\mathrm{C}(\mathrm{SOC})$ and soil inorganic carbon (SIC). The term 'soil-C sequestration' implies the transfer of $\mathrm{CO}_{2}$ into the soil pool through, for example, humification of added biomass (Lal, 2007). Current research on $C$ sequestration considers the total SOC change. On the other hand, other authors divide SOC into labile and recalcitrant pools by using acid hydrolysis. ${ }^{14} \mathrm{C}$ radiocarbon studies indicated that hydrolyzable $C$ contains younger $C$ than the corresponding non-hydrolyzable C (Leavitt et al., 1996). Recalcitrant $\mathrm{C}$ was reported to contain, besides humic substances, resistant compounds such as lignin, suberin, fat, cutin, and resins.

An alternative to monitoring the disappearance or sequestration of $\mathrm{C}$ in the soil is the measurement of the rate at which $\mathrm{CO}_{2}$ is produced during amendment decomposition (Rochette et al., 1999). This approach enables the measurement of instantaneous decomposition rates and provides information on the same time scale as do changes in variables that modulate decomposition of residues in the soil (e.g., soil temperature, moisture, and C availability; Rochette et al., 1999).

\section{Materials and methods}

\subsection{Compost preparation and analysis}

The compost used in the experiment was produced in a facility located in northern Italy. It was prepared by using a mixture of food residues and ligno-cellulosic wastes in a $3: 2 \mathrm{v} / \mathrm{v}$ ratio. This mixture was co-composted in an aerated pile and turned every $4-5 \mathrm{~d}$ for $30 \mathrm{~d}$. During the composting process, the pile was watered regularly to maintain water content in the range of 500$600 \mathrm{~g} \mathrm{~kg}^{-1}$. After this period, compost was left to cure for two months. At the end of the curing phase, compost was ground to a size that can pass through a $10-\mathrm{mm}$ mesh and stored for future use. Wet samples were used for moisture, $\mathrm{pH}$, and salinity determinations (US Composting Council, 1997). For the other analyses, a representative sample was dried at $45^{\circ} \mathrm{C}$ and then to $105^{\circ} \mathrm{C}$, and ground to $0.5-\mathrm{mm}$ mesh size. Organic $\mathrm{C}$ was determined by the dichromate-oxidation method (Ciavatta et al., 1989). Nitrogen (N) content was determined by the Kjeldahl digestion method (Jones et al., 1991).

Organic matter fractionation of compost was carried out as previously reported (Adani et al., 1995), obtaining four fractions: fraction I - soluble in benzene/ethanol mixture $(2: 1 \mathrm{v} / \mathrm{v})$ and $16.87 \mathrm{~mol}$ $\mathrm{l}^{-1}$ ethanol (soluble lipids, waxes, soluble tannins, proteins, and fulvic acids); fraction II - soluble in hot $0.94 \mathrm{~mol} \mathrm{l}^{-1} \mathrm{H}_{2} \mathrm{SO}_{4}$ under reflux for $2 \mathrm{~h}$ (hemicellulose, proteins, and fulvic acids); fraction III - soluble in $13.50 \mathrm{~mol} \mathrm{l}^{-1} \mathrm{H}_{2} \mathrm{SO}_{4}$ at $4{ }^{\circ} \mathrm{C}$ for $24 \mathrm{~h}$ (cellulose); and fraction IV - insoluble in any solvent (ligno-humic complex). The sum of fractions I, II, and III, represented the OM labile pool and fraction IV represented the OM recalcitrant pool.

Humic acid (HA), core-HA (core-HA), and fulvic acid (FA) extractions were performed as previously reported (Adani et al., 1995). HA was directly extracted from compost, whereas core-HA was extracted from compost previously purified as described above (see OM fractionation).

In brief, $2 \mathrm{~g}$ of dried compost was extracted with $\mathrm{NaOH}$ plus $\mathrm{Na}_{4} \mathrm{P}_{2} \mathrm{O}_{7}$ solution, at $65^{\circ} \mathrm{C}$. The sample was then cooled to room temperature and centrifuged. The extraction was repeated by adding distilled water until the supernatant was completely clear. The supernatant solution (alkaline extract) was filtered through a $0.45-$ $\mu \mathrm{m}$ Millipore filter, acidified to below $\mathrm{pH} 1.5$, and centrifuged. The insoluble fractions (HA or core-HA) were washed with distilled water to a neutral $\mathrm{pH}$. The ash content of all extracted fractions was less than $1 \%$. The residual alkali-soluble/acid-soluble fraction was purified by chromatography using a polyvinylpirrolidone column, obtaining two fractions: fulvic acid (FA) and non-humified material.

Compost, labile pool, recalcitrant pool, and the HA, FA, and coreHA extracted from compost were quantified by organic $C$ determinations by dichromate oxidation (Ciavatta et al., 1989), obtaining: total organic $\mathrm{C}(\mathrm{TOC})$, labile carbon pool $\left(\mathrm{C}_{\mathrm{I}+\mathrm{II}+\mathrm{III}}\right)$, recalcitrant carbon pool $\left(C_{I V}\right)$, humic acid carbon $(\mathrm{HAC})$, core-HA carbon (core$\mathrm{HAC}$ ), and fulvic acid carbon (FAC).

The OM evolution index (OMEI) was represented by the coreHAC-HAC ratio and was used to evaluate humified OM stability. The OMEI ranges from 0 to 1 , with 1 indicating the upper limit of the maximum stability of HA (Adani et al., 1997).

The biological stability of compost, expressed as the oxygen uptake rate of microorganisms degrading the compost-OM (OUR = $\mathrm{mg} \mathrm{O}_{2} \mathrm{~kg} \mathrm{OM}^{-1} \mathrm{~h}^{-1}$ ), was determined using the dynamic respirometric method reported by Adani et al. (2004), which has an uncertainty of roughly $5-10 \%$. Analysis was performed one time on a representative sample of $13 \mathrm{~kg}$.

\subsection{Field experiment design}

The soil was silty-clay (Fluvic-eutric Cambisol, FAO, 1988) located near Milan (45 $35^{\prime} \mathrm{N}, 9^{\circ} 16^{\prime}$ E, elevation 162 asl), northern Italy (Table 1 ). It was regularly cultivated with maize.

Investigations were carried out during one crop season (MayOctober) on $6 \times 4-\mathrm{m}$ soil plots. Three different treatments were considered: soil without compost amendment (control), soil amended with $50 \mathrm{Mg} \mathrm{ha}^{-1}$ of mature compost, and soil amended with $85 \mathrm{Mg} \mathrm{ha}^{-1}$ of mature compost. Two replicates per treatment were randomly established in a complete random block design. The experiment started in May and ended in October 2005. Maize (Zea mays L. cv. "Lolita" - hybrid $\mathrm{F}_{1}$ ) was cropped on the soil. On May 11th, soil was plowed; on May 16th compost was distributed. Plots were amended by uniformly applying $50 \mathrm{Mg} \mathrm{ha}^{-1}$ (agronomic 
Table 1

Chemical and physical characteristics of the soil used in the experiment

\begin{tabular}{ll}
\hline Parameter & Value \\
\hline $\mathrm{pH}\left(\mathrm{H}_{2} \mathrm{O} ;-\log \left[\mathrm{H}^{+}\right]\right)$ & $6.69 \pm 0.13$ \\
$\mathrm{Sand}\left(\mathrm{g} \mathrm{kg}^{-1} \mathrm{dm}^{\mathrm{a}}\right)$ & $461.5 \pm 2.4$ \\
$\mathrm{Silt}\left(\mathrm{g} \mathrm{kg}^{-1} \mathrm{dm}\right)$ & $446.8 \pm 3.7$ \\
$\mathrm{Clay}\left(\mathrm{g} \mathrm{kg}^{-1} \mathrm{dm}\right)$ & $91.7 \pm 1.4$ \\
$\mathrm{C}$ org. $\left(\mathrm{g} \mathrm{kg}^{-1} \mathrm{dm}\right)$ & $18.75 \pm 0.6$ \\
$\mathrm{~N}-\mathrm{Kjeldahl}\left(\mathrm{g} \mathrm{kg}^{-1} \mathrm{dm}\right)$ & $1.86 \pm 0.13$ \\
$\mathrm{C} / \mathrm{N}($ dimensionless$)$ & 10.08 \\
$\mathrm{P}_{2} \mathrm{O}_{5}$ olsen $\left(\mathrm{mg} \mathrm{kg}^{-1}\right)$ & $106.9 \pm 16.9$ \\
Exchangeable-K $\left(\mathrm{mg} \mathrm{kg}^{-1} \mathrm{dm}\right)$ & $248 \pm 14$ \\
$\mathrm{CEC}\left(\mathrm{cmol}^{+} \mathrm{kg}^{-1} \mathrm{dm}^{-}\right.$ & $12.1 \pm 0.2$ \\
Bulk density $\left(\mathrm{g} \mathrm{cm}^{-3}\right)$ & $1.54 \pm 0.11$ \\
Soil depth $(\mathrm{cm})$ & 20 \\
Soil weight $(\mathrm{depth} 20 \mathrm{~cm} ; \mathrm{Mg})$ & 3080
\end{tabular}

a dm: dry matter.

dose) and $85 \mathrm{Mg} \mathrm{ha}^{-1}$ (enrichment dose) mature compost over the plots (on wet-weight basis). The soil was then fine-tilled, mixing compost in the first $20 \mathrm{~cm}$, and prepared for sowing. On May 24th, maize was sown; spacing between rows was $0.70 \mathrm{~m}$ with approximately $0.22 \mathrm{~m}$ within rows (eight plants $\mathrm{m}^{-2}$ ). Then, on June 20th and 26th, $\mathrm{N}$ fertilization was done by applying 175 and $217 \mathrm{~kg} \mathrm{ha}^{-1}$ of urea, respectively. No P and $\mathrm{K}$ fertilization was necessary. Maize was harvested on October 10th.

Total rainfall during the experimental period was $160 \mathrm{~mm}$ from May to July and $144 \mathrm{~mm}$ from August to October. Soil plots were irrigated when necessary. Mean temperature was $21.7^{\circ} \mathrm{C}$.

\subsection{Soil sampling and analysis}

Before sowing (on May 24th; time $=0 \mathrm{~d}$ : $t_{0}$ ) and after the maize harvest (on October 19 th) (time $=150 \mathrm{~d}$ : $t_{150}$ ), six soil core samples $20 \mathrm{~cm}$ in diameter and comprising the top $20 \mathrm{~cm}$ were randomly taken from each plot. To make a composite sample, soil cores of approximately 300-400 g were mixed and successively sampled to obtain one analytical sample plot. Samples were then air-dried, sieved to $2 \mathrm{~mm}$, ground to $0.5 \mathrm{~mm}$, mixed, and then stored. Soil $\mathrm{pH}$ was determined in aqueous solution using a 1:2.5 soil-water ratio, total $\mathrm{N}$ determined by the Kjeldahl method, organic $\mathrm{C}$ determined by dichromate oxidation, cation exchange capacity determined by saturating the soil with $\mathrm{BaCl}_{2}$, and texture determined by the pipette method (ASA, SSSA, 1982). Soil bulk density was determined as reported in the MPAF Methods (1997). All analyses were made in triplicate.

\subsection{Open-field $\mathrm{CO}_{2}$ flux measurements}

$\mathrm{CO}_{2}$ measurements were made by using a $\mathrm{CO}_{2}$ analyzer (COMBI$\mathrm{CO}_{2}$, COSTHEC, Milan, Italy). The $\mathrm{CO}_{2}$-measuring apparatus consisted of a steel funnel (5-l volume) (COSTECH, Milan, Italy), two thermometric probes (Pt 100, Instrumentation Laboratory, Milano, Italy), a $\mathrm{CO}_{2}$ glass electrode (Instrumentation Laboratory, Milano, Italy), and a data logger (COSTECH, Milan, Italy). The steel funnel functioned as the measurement chamber. The funnel was positioned on the soil with the border at a soil depth of $5 \mathrm{~cm} . \mathrm{CO}_{2}$ from the soil accumulated in the chamber, allowing $\mathrm{CO}_{2}$ concentration $(\mathrm{v} / \mathrm{v})$ to be measured every $60 \mathrm{~s}$ for a period no longer than $60 \mathrm{~min}$ (generally $30-40 \mathrm{~min}$ ) by the electrode at the top of the funnel. The first 5 min were discharged. The measurement time allowed the cumulative $\mathrm{CO}_{2}$ curve to remain linear, indicative of a correct measurement (Naganawa and Kyuma, 1991). With increased measurement times, linearity was lost (data not shown), presumably due to the negative effects of $\mathrm{CO}_{2}$ accumulation on soil respiration (Naganawa and Kyuma, 1991). The $\mathrm{CO}_{2}$ results were expressed as $\mathrm{g} \mathrm{CO}_{2} \mathrm{~m}^{-2} \mathrm{~h}^{-1}$, taking into consideration the duration of the measurement $(\mathrm{h})$, the area of the funnel $\left(0.0434 \mathrm{~m}^{2}\right)$, and the slope of the $\mathrm{CO}_{2}$ curve during the measurement.

During each $\mathrm{CO}_{2}$ measurement, both moisture content and temperature $(T)$ were determined. Air temperature was measured at a height of $0.5 \mathrm{~m}$, while soil temperature was measured at a $10-\mathrm{cm}$ depth. Soil moisture content in the top 2-20-cm layer was measured by collecting a representative soil thesis after each $\mathrm{CO}_{2}$ measurement.

$\mathrm{CO}_{2}$ measurements were made for all six soil plots on the same day between $11 \mathrm{am}$ and $1 \mathrm{pm}$ on May 30th, June 23rd, July 14th, July 28th, August 21st and October 1st. The first measurement was made after compost amendment and maize sowing; the last measurement corresponded to the time of plant senescence.

\subsection{Statistical method}

The results were analyzed by ANOVA, considering the treatments as independent variables. Values of the means were separated by Tukey's test, considering a significance level of $P<0.05$.

\section{Results and discussion}

\subsection{Compost characteristics}

The compost used in this experiment exhibited an alkaline $\mathrm{pH}$, a medium TOC, and a low $\mathrm{C} / \mathrm{N}$ (Table 2). Compost OM showed a high degree of humification as the sum of HAC and FAC accounted for $510 \mathrm{~g} \mathrm{~kg}^{-1}$ of the TOC (Table 2). These data suggested that the compost had a high degree of evolution, which was confirmed by the OUR, the recalcitrant fraction content, and OMEI. An OUR of $359 \mathrm{mg} \mathrm{O}_{2} \mathrm{~kg} \mathrm{OM}^{-1} \mathrm{~h}^{-1}$ (Table 2) is indicative of a well-stabilized compost, whereas an OUR of $500 \mathrm{mg} \mathrm{O}_{2} \mathrm{~kg} \mathrm{OM}^{-1} \mathrm{~h}^{-1}$ and $1000 \mathrm{mg}$ $\mathrm{O}_{2} \mathrm{~kg} \mathrm{OM}^{-1} \mathrm{~h}^{-1}$ is indicative of the upper limits defining high and medium biological compost stability, respectively (Adani et al., 2004). The OM fractionation indicated that the compost-OM contained $520 \mathrm{~g} \mathrm{~kg}^{-1}$ OM of labile OM (lipid, cellulose, hemicelluloses, and protein) and $480 \mathrm{~g} \mathrm{~kg}^{-1} \mathrm{OM}$ of recalcitrant $\mathrm{OM}$ (non-hydrolyzable OM, i.e., ligno-humic complex; Adani et al., 1995). These latter data were very high, considering that Rovira and Vallejo (2002) reported a Klason lignin content for Medicago, Eucalyptus, Quercus, and Pinus of $173,212,302$, and $316 \mathrm{~g} \mathrm{~kg}^{-1} \mathrm{OM}$, respectively (Klason lignin was obtained by a method similar to that used in this work to obtain the recalcitrant fraction).

Table 2

Characteristics of the composts used in the experiment

\begin{tabular}{|c|c|c|c|}
\hline Parameters & Value & Organic matter fractions & \\
\hline $\mathrm{pH}\left(1: 5 ;-\log \left[\mathrm{H}^{+}\right]\right)$ & $8.80 \pm 0.35$ & & \\
\hline $\mathrm{EC}\left(\mathrm{dS} \mathrm{cm} \mathrm{cm}^{-1}\right)$ & $0.27 \pm 0.38$ & $\begin{array}{l}\text { Fraction I } \\
\left(\mathrm{g} \mathrm{kg}^{-1} \mathrm{OM}_{\text {comp }}\right)^{\mathrm{a}}\end{array}$ & $33.1 \pm 5.3$ \\
\hline $\begin{array}{l}\text { Moisture content (g } \\
\left.\mathrm{kg}^{-1} \mathrm{dm}\right)\end{array}$ & $346.1 \pm 0.1$ & $\begin{array}{l}\text { Fraction II } \\
\left(\mathrm{g} \mathrm{kg}^{-1} \mathrm{OM}_{\mathrm{comp}}\right)^{\mathrm{a}}\end{array}$ & $319.5 \pm 39.0$ \\
\hline TOC $\left(\mathrm{g} \mathrm{kg}^{-1} \mathrm{dm}\right)$ & $198.9 \pm 17.1$ & $\begin{array}{l}\text { Fraction III } \\
\left(\mathrm{g} \mathrm{kg}^{-1} \mathrm{OM}_{\text {comp }}\right)^{\mathrm{a}}\end{array}$ & $167.5 \pm 16.9$ \\
\hline \multirow[t]{3}{*}{$\mathrm{N}$-Kjeldhal $\left(\mathrm{g} \mathrm{kg}^{-1} \mathrm{dm}\right)$} & $13.4 \pm 1.3$ & $\begin{array}{l}\text { Fraction IV } \\
\left(\mathrm{g} \mathrm{kg}^{-1} \mathrm{OM}_{\text {comp }}\right)^{\mathrm{a}}\end{array}$ & $479.9 \pm 23.6$ \\
\hline & & $\mathrm{C}_{\mathrm{I}+\mathrm{II}+\mathrm{III}} \mathrm{b}\left(\mathrm{gkg}^{-1} \mathrm{OM}_{\mathrm{lab}}\right)^{\mathrm{a}}$ & $438 \pm 23$ \\
\hline & & $C_{I V}^{b}\left(\mathrm{~g} \mathrm{~kg}^{-1} \mathrm{OM}_{\mathrm{rec}}\right)^{\mathrm{a}}$ & $619 \pm 17$ \\
\hline $\mathrm{C}_{\mathrm{HA}}\left(\mathrm{g} \mathrm{kg}^{-1} \mathrm{dm}\right)$ & $87.1 \pm 26.7$ & & \\
\hline $\mathrm{C}_{\mathrm{FA}}\left(\mathrm{g} \mathrm{kg}^{-1} \mathrm{dm}\right)$ & $14.8 \pm 2.1$ & $\mathrm{OMEI}^{\mathrm{c}}$ (dimensionless) & 0.70 \\
\hline $\mathrm{C} / \mathrm{N}$ dimensionless & 14.8 & $\begin{array}{l}\mathrm{OUR}^{\mathrm{d}}\left(\mathrm{mg} \mathrm{O}_{2} \mathrm{~kg}\right. \\
\left.\mathrm{OM}^{-1} \mathrm{~h}^{-1}\right)\end{array}$ & 359 \\
\hline
\end{tabular}

${ }^{\mathrm{a}} \mathrm{OM}_{\mathrm{comp}}=$ compost $\mathrm{OM} ; \mathrm{OM}_{\mathrm{lab}}=$ labile $\mathrm{OM} ; \mathrm{OM}_{\mathrm{rec}}=$ recalcitrant $\mathrm{OM}$.

b $\mathrm{C}$ contents of the labile and recalcitrant fractions.

c Organic matter evolution index (see text).

d Oxygen uptake rate (see text). 
Table 3

Soil characteristics at the beginning and at the end of the experiment

\begin{tabular}{|c|c|c|c|c|c|c|}
\hline & \multicolumn{2}{|l|}{ Control } & \multicolumn{2}{|c|}{ Compost dose of $50 \mathrm{Mg} \mathrm{ha}^{-1}$} & \multicolumn{2}{|c|}{ Compost dose of $85 \mathrm{Mg} \mathrm{ha}^{-1}$} \\
\hline & $t_{0}$ & $t_{150}$ & $t_{0}{ }^{\mathrm{a}}$ & $t_{150}$ & $t_{0}{ }^{a}$ & $t_{150}$ \\
\hline $\mathrm{pH}$ & $7.29 \pm 0.01^{b} a^{c}$ & $7.50 \pm 0.13 a$ & $7.51 \pm 0.22 \mathrm{ab}$ & $7.51 \pm 0.15 a$ & $7.67 \pm 0.25 \mathrm{~b}$ & $7.75 \pm 0.01 b$ \\
\hline$C\left(\mathrm{~g} \mathrm{~kg}^{-1} \mathrm{dm}^{\mathrm{d}}\right)$ & $18.36 \pm 0.03 a$ & $18.43 \pm 0.45 a$ & $20.12 \pm 0.61 c(21.08)^{e}$ & $19.08 \pm 0.40 \mathrm{~b}$ & $22.17 \pm 0.11 d(23)^{e}$ & $20.41 \pm 0.00 c$ \\
\hline $\mathrm{N}-K j e l d a h l\left(\mathrm{~g} \mathrm{~kg}^{-1} \mathrm{dm}\right)$ & $1.93 \pm 0.02 a$ & $1.91 \pm 0.01 \mathrm{a}$ & $1.98 \pm 0.02 \mathrm{a}$ & $2.09 \pm 0.03 \mathrm{ab}$ & $2.23 \pm 0.21 b$ & $2.10 \pm 0.10 b$ \\
\hline $\mathrm{C} / \mathrm{N}$ & 9.51 & 9.85 & 10.16 & 9.13 & 9.94 & 9.72 \\
\hline $\mathrm{CEC}\left(\mathrm{cmol}^{+} \mathrm{kg}^{-1} \mathrm{dm}\right)$ & $11.97 \pm 0.00 a$ & $11.79 \pm 0.92 a$ & $11.45 \pm 1.01 \mathrm{a}$ & $12.36 \pm 1.14 a$ & $14.01 \pm 0.27 b$ & $14.36 \pm 0.37 b$ \\
\hline
\end{tabular}

a Parameters determined after compost addition.

b Mean and standard deviation calculated from data obtained from two plots.

c Means followed in the same line by the same letter are not statistically different $(P<0.05)$ according to Tukey's test.

d Dry matter.

e Theoretical soil-C content at time $t_{0}$ calculated as the sum of soil-C in the control at time $t_{0}$ and the total C added with the compost doses: $2.72 \mathrm{~g} \mathrm{C} \mathrm{kg}^{-1}$ of soil for dose $50 \mathrm{Mg} \mathrm{ha}^{-1}$ and $4.64 \mathrm{Mg} \mathrm{ha}^{-1}$ for the dose $85 \mathrm{Mg} \mathrm{ha}^{-1}$.

The HA fraction possessed high chemical stability, as suggested by an OMEI of 0.7 (Table 2), close to the maximum value of 1 (scale of $0-1$ for chemical stability; Adani et al., 1997).

\subsection{Soil carbon}

The $\mathrm{C}$ content of the control remained constant during the trial (difference was not statistically significant). This fact suggested that net $\mathrm{C}$ production of the maize plants during the growing season (e.g., roots, exudates, etc.) was equal to $C$ mineralization, a fact previously reported for arable soil (Larionaova et al., 1998). The treatments amended with compost contained a higher $C$ content than the control at both beginning and end of the experiment (Table 3 ). We thus concluded that compost addition affected soil$C$ content and that the $C$ increase depending on the amount of compost added, confirming previous findings (Giusquiani et al., 1995; Izaurralde et al., 2001).

Taking into consideration the starting $\left(t_{0}\right)$ and final $\left(t_{150}\right)$ soil- $C$ contents for both amended treatments (Table 3 ), it can be calculated that $C$ content decreased by $1.04 \mathrm{~g} \mathrm{~kg}^{-1}$ of soil (i.e., $20.12-$ $19.08 \mathrm{~g} \mathrm{C} \mathrm{kg}^{-1}$ of soil (Table 3)) and $1.76 \mathrm{~g} \mathrm{~kg}^{-1}$ of soil (i.e., 22.17-20.41 $\mathrm{g} \mathrm{kg}^{-1}$ of soil (Table 3)) for soil amended with $50 \mathrm{Mg} \mathrm{ha}^{-1}$ and $85 \mathrm{Mg} \mathrm{ha}^{-1}$, respectively. On the other hand, the $\mathrm{C}$ added to the soils with compost, calculated from the amount and TOC content of compost and compost doses, were $2.72 \mathrm{~g} \mathrm{C}$ $\mathrm{kg}^{-1}$ soil and of $4.64 \mathrm{~g} \mathrm{C} \mathrm{kg}^{-1}$ soil, respectively, for the lowest and highest compost dose. Thus, considering that no $C$ content variation occurred in the control soil and that no differences in crop yields occurred in the different treatments at the end of the experiment (Tambone et al., 2007), it could be calculated that, for compost doses 50 and $85 \mathrm{Mg} \mathrm{ha}^{-1}, 369 \mathrm{~g} \mathrm{C} \mathrm{kg}^{-1}(40 \%)$, and $520 \mathrm{~g} \mathrm{C} \mathrm{kg}^{-1}$ (53\%) of the carbon added was retained.

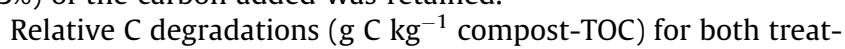
ments were not much different from the relative content of labile $\mathrm{C}$ in compost, which was $414 \mathrm{~g} \mathrm{C} \mathrm{kg}^{-1} \mathrm{TOC}$, calculated by using data on relative $C$ contents of the labile and recalcitrant fractions $\left(\mathrm{g} \mathrm{kg}^{-1}\right.$ $\mathrm{OM}_{\mathrm{lab}}$ or $\mathrm{OM}_{\mathrm{rec}}$ ) and the relative fraction contents of compost ( $\mathrm{g}$ $\mathrm{kg}^{-1} \mathrm{OM}_{\text {comp }}$; Table 2). Therefore, these results suggest that, after $150 \mathrm{~d}$ of compost application, the labile fraction was completely degraded and the recalcitrant fraction had not been degraded. The non-hydrolyzable OM (biochemically protected OM), i.e., the recalcitrant fraction was previously shown to be the fraction that contributes to the stable OM of soil (Rovira and Vallejo, 2002; Mikutta et al., 2006).

These data point to a slight increase in the fraction of $C$ retained with compost dose. This is in contrast with literature data that showed constant or decreasing percentage of $C$ accumulation with increasing dose of OM application (Körschens and Müller, 1996; Smith et al., 2000). One possible explanation is that the compost used in this experiment was highly stable with a recalcitrant fraction over $50 \%$, and other experiments might have used more degradable compost. Since little differences in the evaluation of soil-C content may result in high differences when considering soil-C sequestration, the consideration reported above needs further confirmation and research. Indications of this are provided by the fact that measured soil- $\mathrm{C}$ in amended soil at $t_{0}$ was different from the expected soil-C contents calculated basing on $C$ content of control and the total $\mathrm{C}$ added to the soil with compost above all for compost dose of $50 \mathrm{Mg} \mathrm{ha}^{-1}$ (Table 3).

\subsection{Soil carbon dioxide fluxes}

The measurement of $\mathrm{CO}_{2}$ fluxes in the soil is the most direct method of measuring microbial activity under aerobic condition (ASA, SSSA, 1982). Respiration has also successfully been used in the past to describe $C$ mineralization and $C$ stabilization after the addition of organic materials into the soil (ASA, SSSA, 1982). Therefore, our data on $\mathrm{CO}_{2}$ fluxes obtained from this work can be used to further investigate the fate of compost $\mathrm{C}$ in the soil.

Table 4

$\mathrm{CO}_{2}$-fluxes measured during the experiment for control and soils amended with $50 \mathrm{Mg} \mathrm{ha}^{-1}$ and $85 \mathrm{Mg} \mathrm{ha}^{-1}$

\begin{tabular}{lc}
\hline Sampling date & Mean \\
\hline Control plots $\left(\mathrm{g} \mathrm{CO}_{2} \mathrm{~m}^{-2} h^{-1}\right)$ & $0.39 \pm 0.03^{\mathrm{a}} \mathrm{aA} \mathrm{b}^{\mathrm{b}}$ \\
$30 / 05 / 2005$ & $0.62 \pm 0.22 \mathrm{bA}$ \\
$23 / 06 / 2005$ & $0.60 \pm 0.09 \mathrm{bA}$ \\
$14 / 07 / 2005$ & $0.82 \pm 0.12 \mathrm{cA}$ \\
$28 / 07 / 2005$ & $0.76 \pm 0.1 \mathrm{BcA}$ \\
$21 / 08 / 2005$ & $1.23 \pm 0.41 \mathrm{dA}$ \\
$01 / 09 / 2005$ & $0.92 \pm 0.02^{\mathrm{a}} \mathrm{aB}$ \\
Plots amended with compost (dose $\left.50 \mathrm{Mg} \mathrm{ha}^{-1}\right)\left(\mathrm{CO}_{2} \mathrm{~m}^{-2} h^{-1}\right)$ \\
$30 / 05 / 2005$ & $0.86 \pm 0.13 \mathrm{aB}$ \\
$23 / 06 / 2005$ & $0.87 \pm 0.12 \mathrm{aB}$ \\
$14 / 07 / 2005$ & $0.99 \pm 0.11 \mathrm{bA}$ \\
$28 / 07 / 2005$ & $0.90 \pm 0.07 \mathrm{aB}$ \\
$21 / 08 / 2005$ & $1.19 \pm 0.04 \mathrm{bA}$ \\
$01 / 09 / 2005$ & $1.08 \pm 0.1^{\mathrm{a}} \mathrm{aB}$ \\
Plots amended with compost (dose $\left.85 \mathrm{Mg} \mathrm{ha}^{-1}\right)\left(g \mathrm{CO}_{2} \mathrm{~m}^{-2} h^{-1}\right)$ \\
$30 / 05 / 2005$ & $1 \pm 0.11 \mathrm{aB}$ \\
$23 / 06 / 2005$ & $0.93 \pm 0.19 \mathrm{aB}$ \\
$14 / 07 / 2005$ & $1.19 \pm 0.01 \mathrm{aB}$ \\
$28 / 07 / 2005$ & $1.03 \pm 0.18 \mathrm{aB}$ \\
$21 / 08 / 2005$ & $1.2 \pm 0.2 \mathrm{BA}$ \\
$01 / 09 / 2005$ &
\end{tabular}

a Mean and standard deviation calculated form data obtained from two plots per treatments.

b Means followed by the same letter for the same treatment are not statistically different $(P<0.05)$ according to Tukey's test, within the same column (different date; small letter) and between different treatment for each sampling date (mean value for each treatment; capital letter). 
Within each plot and between treatments, $\mathrm{CO}_{2}$ fluxes were found to be highly homogeneous (Table 4). Average values showed that $\mathrm{CO}_{2}$ fluxes in the control were generally lower than those in the amended treatments. The treatment amended with $85 \mathrm{Mg} \mathrm{ha}^{-1}$ of compost always exhibited higher $\mathrm{CO}_{2}$ flux values than that amended with $50 \mathrm{Mg} \mathrm{ha}^{-1}$ of compost, although no statistical differences were evident. Rochette et al. (1999), studying soil cropped with maize, found $\mathrm{CO}_{2}$ flux ranges between 0.15 and $1.06 \mathrm{~g} \mathrm{CO}_{2}$ $\mathrm{m}^{-2} \mathrm{~h}^{-1}$.

Soil treated with compost showed a relatively constant respiration rate throughout the experiment: $\mathrm{CO}_{2}$ flux of $0.96 \pm 0.11 \mathrm{~g} \mathrm{CO}_{2}$ $\mathrm{m}^{-2} \mathrm{~h}^{-1}$ and $\mathrm{CO}_{2}$ flux of $1.07 \pm 0.10 \mathrm{~g} \mathrm{CO}_{2} \mathrm{~m}^{-2} \mathrm{~h}^{-1}$ for $50 \mathrm{Mg} \mathrm{ha}^{-1}$, and $85 \mathrm{Mg} \mathrm{ha}^{-1}$, respectively. In contrast, respiration rate increased during the experiment in the control $\left(\mathrm{CO}_{2}\right.$ flux of $0.39 \pm 0.03 \mathrm{~g} \mathrm{CO}_{2} \mathrm{~m}^{-2} \mathrm{~h}^{-1}$ on May 30th, 2005 and of $1.23 \pm 0.41 \mathrm{~g}$ $\mathrm{CO}_{2} \mathrm{~m}^{-2} \mathrm{~h}^{-1}$ on September 1st, 2005) (Fig. 1a). It appears that, during the growing season, respiration rates in the control plots increased due to the increase of root respiration and related processes (e.g., respiration of root exudates). The $\mathrm{CO}_{2}$ flux measured in the control can be assumed as basal soil respiration (root plus microbial respiration) as no differences in plant yield were noted (Tambone et al., 2007). This $\mathrm{CO}_{2}$ flux accounted, on average, for $71-80 \%$ of the total $\mathrm{CO}_{2}$ flux from the amended soil.

The $\mathrm{CO}_{2}$ flux due to compost degradation, calculated by subtracting $\mathrm{CO}_{2}$ flux respiration of the control from those of the amended soils (Fig. 1b), indicated that the treatment using the highest compost dose always had a higher $\mathrm{CO}_{2}$ flux than the treatment with the lowest compost dose, although differences were not statistically significant. On average, the compost dose of
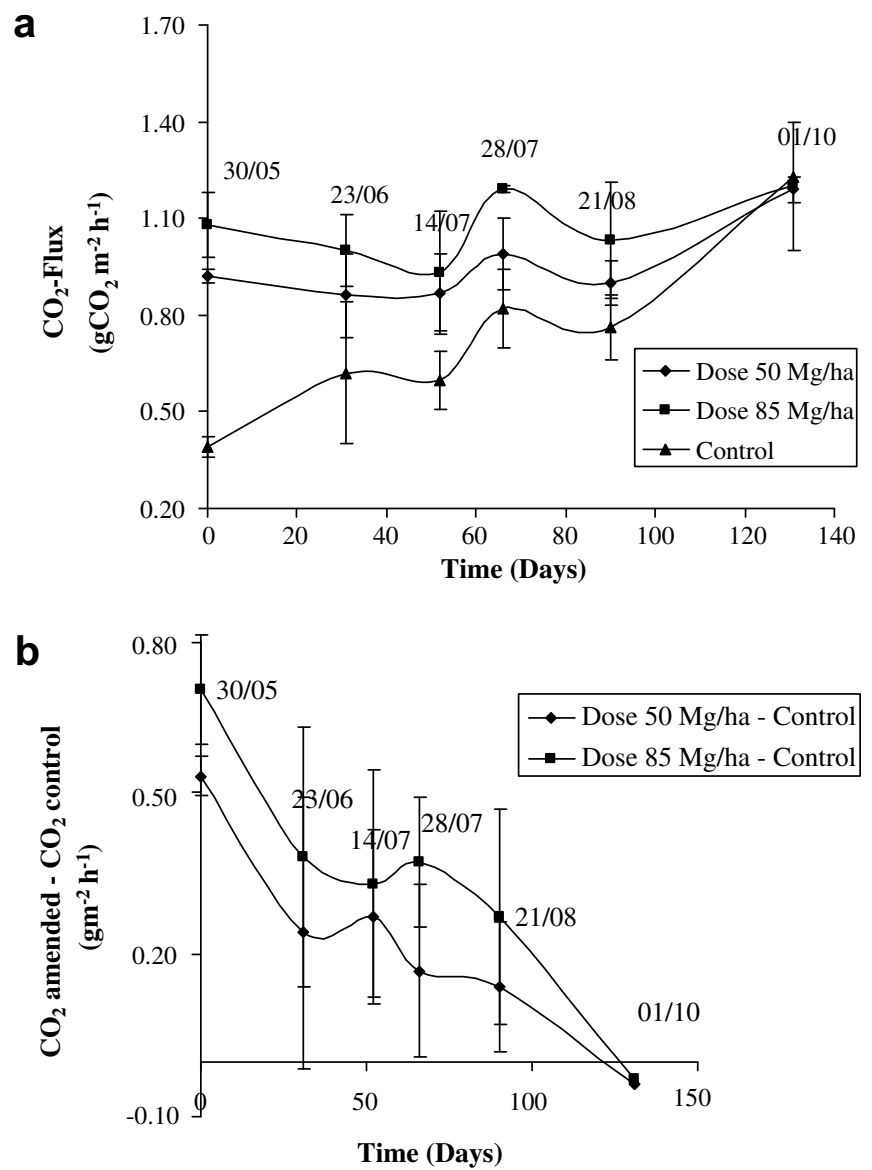

Fig. 1. Soil respiration measured during the experiment for (a) the different treatments and control, and (b) the treatments minus the control.
$50 \mathrm{Mg} \mathrm{ha}^{-1}$ showed a $\mathrm{CO}_{2}$ flux $67 \%$ lower than that of $85 \mathrm{Mg} \mathrm{ha}^{-1}$, probably reflecting the lower total labile $C$ in the soil $(-59 \%)$. The uncertainty associated with these results indicates that it is more difficult to draw conclusions from soil $\mathrm{CO}_{2}$ flux data than from soil carbon data.

\section{Conclusion}

Compost use represents an interesting opportunity to sequester $\mathrm{C}$ in the soil, especially in the light of increasing interest on agricultural compost use. As compost represents "predigested" OM, the high content of recalcitrant-OM allows for high soil-C accumulation levels after a short-time experiment. In this study, both the amount of carbon retained and degraded increased with compost dose. The fraction of the carbon added that was retained appeared to increase slightly with the increased compost dose.

Further investigations are needed to better elucidate on how compost characterization in labile and recalcitrant $\mathrm{C}$ fractions can predict the $\mathrm{C}$ sequestered in the soil in short- and long-term experiments.

\section{References}

Adani, F., Genevini, P.L., Tambone, F., 1995. A new index for compost stability. Compost Science and Utilization 3, 25-37.

Adani, F., Genevini, P.L., Gasperi, F., Zorzi, G., 1997. Organic matter evolution index (OMEI) as a measure of composting efficiency. Compost Science and Utilization 5, 53-62.

Adani, F., Ricca, G., 2004. The contribution of alkali soluble (humic acid-like) and unhydrolyzed-alkali soluble (core-humic acid-like) fractions extracted from maize plant to the formation of soil humic acid. Chemosphere 56, 13-22.

Adani, F., Confalonieri, R., Tambone, F., 2004. Dynamic respiration index as descriptor of the biological stability of organic wastes. Journal of Environmental Quality 33, 1866-1876.

ASA, SSSA, 1982. Methods of Soil Analysis, Part 2. American Society of Agronomy Inc., Soil Science Society of America Inc., Madison.

Ciavatta, C., Vittori Antisari, L., Sequi, P., 1989. Determination of organic carbon in soil and fertilizer. Communication Soil Science Plant Analysis 20, 759-773.

Cole, C., Cerri, C., Minami, K., Mosier, A., Rosemberg, N.J., Sauerbeck, D., 1996. Agricultural options for mitigation of greenhouse gas emission. In: Watso, R.T. Zinowera, M.T., Moss, R.H. (Eds.), Climate Change 1995: Impacts, Adaptation and Mitigation of Climate Change. Cambridge University Press, Cambridge, pp. 745-771 (Chapter 23).

Giusquiani, P.L., Pagliai, M., Gigliotti, G., Businelli, D., Benetti, A., 1995. Urban waste compost: effects on physical, chemical, and biochemical soil properties. Journal of Environmental Quality 24, 175-182.

Gonzàles-Vila, F.J., Almendros, G., Madrid, F., 1999. Molecular alterations of organic fractions from urban waste in the course of composting and their further transformation in amended soil. The Science of the Total Environment 236, 215-229.

Izaurralde, R.C., Rosenberg, N.J., Lal, R., 2001. Mitigation of climatic change by soi carbon sequestration: issues of science, monitoring, and degraded lands. Advances in Agronomy 70, 1-75.

Jones, J.B., Wolf, B., Mills, H.A., 1991. Plant Analysis Handbook. Micro-macro Publishing, Athens.

Körschens, M., Müller, A., 1996. The static experiment Bad Lauchstädt, Germany. In Powlson, D.S., Smith, P., Smith, J.U. (Eds.), Evaluation of Soil Organic Matter Models using Existing, Long-Term Datasets, NATO ASI Series I, vol. 38. Springer, Heidelberg, Germany, pp. 369-376.

Lal, R., 2007. Carbon management in agricultural soils. Mitigation and Adaptation Strategies for Global Change 12, 303-322.

Lal, R., 2001. World cropland soils as a source or sink for atmospheric carbon. Advances in Agronomy 71, 145-191.

Larionaova, A.A., Yermolayev, A.M., Blagodatsky, S.A., Rozanova, L.N., Yevdolkimov, I.V., Orlinsky, D.B., 1998. Soil respiration an carbon balance of gray forest soils as affected by land use. Biology and Fertility Soils 27, 251-257.

Leifeld, J., Siebert, S., Kogel-Knaber, I., 2002. Changes in the chemical composition of soil organic matter after application of compost. European Journal of Soil Science 53, 299-309.

Leavitt, S.W., Follett, R.F., Paul, E.A., 1996. Estimation of slow- and fast-cycling soil organic carbon pools from $6 \mathrm{~N} \mathrm{HCl}$ hydrolysis. Radiocarbon 38, 231-239.

Lhadi, E.K., Tazi, H., Aylaj, M., Genevini, P.L., Adani, F., 2006. Organic matter evolution during co-composting of the organic fraction of municipal solid waste and poultry manure. Bioresource Technology 97, 2117-2123.

Mikutta, R., Kleber, M., Torn, M.S., Jahn, R., 2006. Stabilization of soil organic matter: association with minerals or chemical recalcitrance? Biogeochemistry 77, 2556.

Mosier, A.R., 1998. Soil processes and global change. Biology and Fertility Soils 27. 221-229. 
MPAF - Ministero delle Politiche Agricole e Forestali, 1997. Metodi Di Analisi Fisica Del Suolo. Franco Angeli Press, Milano, Italy, pp. 4-6 (Chapter II).

Naganawa, T., Kyuma, K., 1991. Concentration dependence of $\mathrm{CO}_{2}$ evolution from soil in chamber with low $\mathrm{CO}_{2}$ concentration $(<2,000 \mathrm{ppm})$ and $\mathrm{CO}_{2}$ diffusion/ sorption model in soil. Soil Science Plant Nutrition 37, 381-386.

Paustian, K., Andrén, O., Janzen, H.H., 1997. Agricultural soils as a sink to mitigate $\mathrm{CO}_{2}$ emission. Soil Use and Management 13, 230-244.

Quèdraogo, E., Mando, A., Zombrè, N.P., 2001. Use of compost to improve soil properties and crop productivity under low input agricultural system in West Africa. Agricultural Ecosystem and Environment 84, 259-266.

Richard, T.L., Woodbury, P.B., 1992. Impact of separation strategies on heavy metal contaminants in MSW compost. Biomass and Bioenergy 3, 195-201.

Rochette, P., Angers, D.A., Flanagan, L.B., 1999. Maize rate decomposition measurement using soil surface carbon dioxide fluxes and natural abundance of carbon-13. Soil Science Society American Journal 63, 1385-1396.

Rovira, P., Vallejo, V.R., 2002. Labile and recalcitrant pools of carbon and nitrogen in organic matter decomposing at different depths in soil: an acid hydrolysis approach. Geoderma 107, 109-141.

Six, J., Conant, R.T., Paul, E.A., Paustian, E.A.P., 2002. Stabilization mechanism of soil organic matter: implication for C-saturation of soil. Plant and Soil 241, 155-176.
Smith, P., Powlson, D.S., Smith, J.U., Falloon, P., Coleman, K., 2000. Meeting Europe's climate change commitments: quantitative estimates of the potential for carbon mitigation by agriculture. Global Change Biology 6, 525-539.

Smith, P., Andrén, O., Karlsson, T., Perälä, P., Regina, K., Rounsevell, M., Van Wesemaels, B., 2005. Carbon sequestration potential in Europe cropland has been overestimated. Global Change Biology 11, 2153-2163.

Tambone, F., Genevini, P.L., Adani, F., 2007. The effects of the short-term compost application on soil chemical properties and plant nutritional status. Compost Science and Utilization 15, 176-183.

The US Composting Council, 1997. Test methods for the examination of composting and compost. The US Composting Council, Bethesda, MD, USA

Vleeshouwers, L.M., Veraghen, A., 2002. Carbon emission and sequestration by agricultural land use. A model study for Europe. Global Change Biology 8, 519530.

Wang, W.J., Baldock, J.A., Dalal, R.C., Moody, P.W., 2004. Decomposition dynamics of plant materials in relation to nitrogen availability and biochemistry determined by NMR and wet-chemical analysis. Soil Biology and Biochemistry 36, 20452058. 